Article

\title{
Mycobacterium avium Subspecies paratuberculosis: Human Exposure through Environmental and Domestic Aerosols
}

\author{
Glenn Rhodes ${ }^{1}$, Hollian Richardson ${ }^{2}$, John Hermon-Taylor ${ }^{3}$, Andrew Weightman ${ }^{4}$, \\ Andrew Higham ${ }^{5}$ and Roger Pickup ${ }^{2, *}$
}

1 Centre for Ecology and Hydrology, Lake Ecosystems Group, Lancaster Environment Centre, Library Avenue, Bailrigg, Lancaster LA1 4AP, UK; E-Mail: Glenn@ceh.ac.uk

2 Faculty of Health and Medicine, Division of Biomedical and Life Sciences, Lancaster University, Lancaster LA1 4YQ, UK; E-Mail: h.richardson2@lancaster.ac.uk

3 Division of Diabetes and Nutritional Sciences, Franklin-Wilkins Building, King's College London, 150 Stamford Street, London SE1 9NH, United Kingdom; E-Mail: j.hermon@kcl.ac.uk

4 Cardiff School of Biosciences, Main Building, Museum Avenue, Cardiff CF10 3AT, UK;

E-Mail: a.weightman@cardiff.ac.uk

5 Royal Lancaster Infirmary, Ashton Road, Lancaster, Lancashire LA1 4RP, UK;

E-Mail: Andrew.Higham@mbht.nhs.uk

* Author to whom correspondence should be addressed; E-Mail: r.pickup@lancaster.ac.uk;

Tel.: +44-1524-593-746; Fax: +44-1524-593-192.

Received: 30 April 2014; in revised form: 1 July 2014 / Accepted: 11 July 2014 /

Published: 16 July 2014

\begin{abstract}
Mycobacterium avium subspecies paratuberculosis (Map) causes Johne's disease in animals and is significantly associated with Crohn's disease (CD) in humans. Our previous studies have shown Map to be present in U.K. rivers due to land deposition from chronic livestock infection and runoff driven by rainfall. The epidemiology of CD in Cardiff showed a significant association with the River Taff, in which Map can be detected on a regular basis. We have previously hypothesized that aerosols from the river might influence the epidemiology of CD. In this preliminary study, we detected Map by quantitative PCR in one of five aerosol samples collected above the River Taff. In addition, we examined domestic showers from different regions in the U.K. and detected Map in three out of 30 independent samples. In detecting Map in river aerosols and those from domestic showers, this is the first study to provide evidence that aerosols are an exposure route for Map to humans and may play a role in the epidemiology of CD.
\end{abstract}


Keywords: Mycobacterium avium subspecies paratuberculosis; Crohn's disease; aerosols; rivers; domestic showers; exposure

\section{Introduction}

Mycobacterium avium subspecies paratuberculosis (Map) is a member of the Mycobacterium avium complex [1,2]. It has the specific ability to cause chronic inflammation of the intestine, or Johne's disease (JD) [3-5], which can affect many animal species, including primates [6,7]. This enteric pathogen is significantly associated with chronic inflammation of the intestine of the Crohn's disease $(C D)$ type in humans [8-10].

Subclinical infection is widespread in domestic livestock, especially cattle, sheep and goats [3]. Infection and disease has now spread worldwide [11,12], with Europe and North America being particularly affected $[3,13]$. It is estimated that the herd prevalence for JD in cattle in the USA is $68 \%$ [14] and $32 \%$ in U.K. $[3,15,16]$. Both clinically and sub-clinically infected animals can shed Map in variable numbers on to pasture in their faeces, depending on the animal, the pathogen strain and the disease characteristics [6]. The organism can survive for many months in agricultural slurry and in the wider environment [17-20].

Rain falling onto pastures contaminated with Map washes it into surface waters and into rivers [19,20]. Previously, we showed that Map was present in 32\% of samples taken from the River Taff (Cardiff, South Wales, UK) and its presence was almost predictable from rain fall patterns and river flow [19], whereas its frequency in samples from the River Tywi was $69 \%$ and its presence predictable [20]. Furthermore, deposition and transport from the catchment was extensive in that Map was maintained in the river for several weeks at a time and was a consequence of the endemic presence of Map in cattle in the Taff catchment [19]. Pickup and co-workers [20] modelled the main human exposure routes of Map and suggested that although driven by shedding from clinically and sub-clinically infected animals, the presence and distribution of Map in the environment may also be influenced by other factors, such as slurrying and soil redistribution from water treatment that recycles Map back from the catchment to the river [19,20]. Water from rivers or reservoirs is used for abstraction and public supply. Inevitably Map has been detected in the drinking water supply systems [20-26]. Furthermore, mycobacteria, including $M$. avium subspecies avium, have been found in domestic showers [27-29].

Cardiff has one of the highest incidences of CD in the U.K., with a corrected incidence for the decade (1996-2005) of 6.6 per $10^{5}$ population per year (with a $95 \%$ confidence interval of 58-76) with a concomitant increase in incidence in children under 16 [30,31]. This compares with 5.6 per $10^{5}$ population per year (with a 95\% confidence interval of 44-68) for the period 1991-1995 [32], 5.9/10\%/year for 1986-1990 [33] and 5.0/105/year over the period from 1976 to 1980 [34]. The epidemiological study carried out by Mayberry and Hitchens in the late 1970s [35] examined the incidence and geographical distribution of Crohn's disease and ulcerative colitis in 25 electoral wards in the city of Cardiff. They found a statistically highly significant $(p<0.001)$ increase in the incidence of Crohn's disease, but not of ulcerative colitis, in 11 of the city wards. Although eight of these 
high-incidence wards bordered the River Taff, their apparent geographical relationship with the river was not statistically significant [35,36]. Figure 1B shows the city of Cardiff with an indication of the direction of the prevailing south westerly winds [19]. The distribution of the wards with a high incidence of Crohn's disease throughout the city is shown in Figure 1B [19]. The topography of the approaches to the southwest aspect of the river is characterized by hills to the north and south. The valley in between, open to the prevailing winds, is directly opposite the gap in the centre of the high-incidence wards on the windward bank of the river. On the leeward side, three additional high-incidence wards lie immediately adjacent to those bordering the river to the northeast. Previously, we suggested that this is the direction in which aerosols containing Map would be carried on the prevailing south westerly winds and proposed that, through aerosolisation of Map, this exposure route is an explanation for the observed disease clusters around the River Taff [19].

Figure 1. Relationship between disease clusters and prevailing wind in Cardiff, Wales, United Kingdom. (A) Location of the city of Cardiff within the UK (red dot); (B) distribution of the 11 electoral wards (shown with black boundaries) in the city of Cardiff that were shown previously $(53,54)$ to have a highly significant $(p<0.001)$ increase in the incidence of Crohn's disease. The wards with the high incidence of Crohn's disease are seen to lie along the River Taff (blue), which flows into the Bristol Channel (blue), with the exception of a gap in the centre stretch of the windward right bank of the river (facing downstream). This gap directly faces a valley between hills to the north and south, which is open to the prevailing southwesterly winds (black arrow; with permission from [19]). The dashed line represents the continuation of the coast. The white bar represents $3 \mathrm{~km}$. The red dot represents the sampling site.

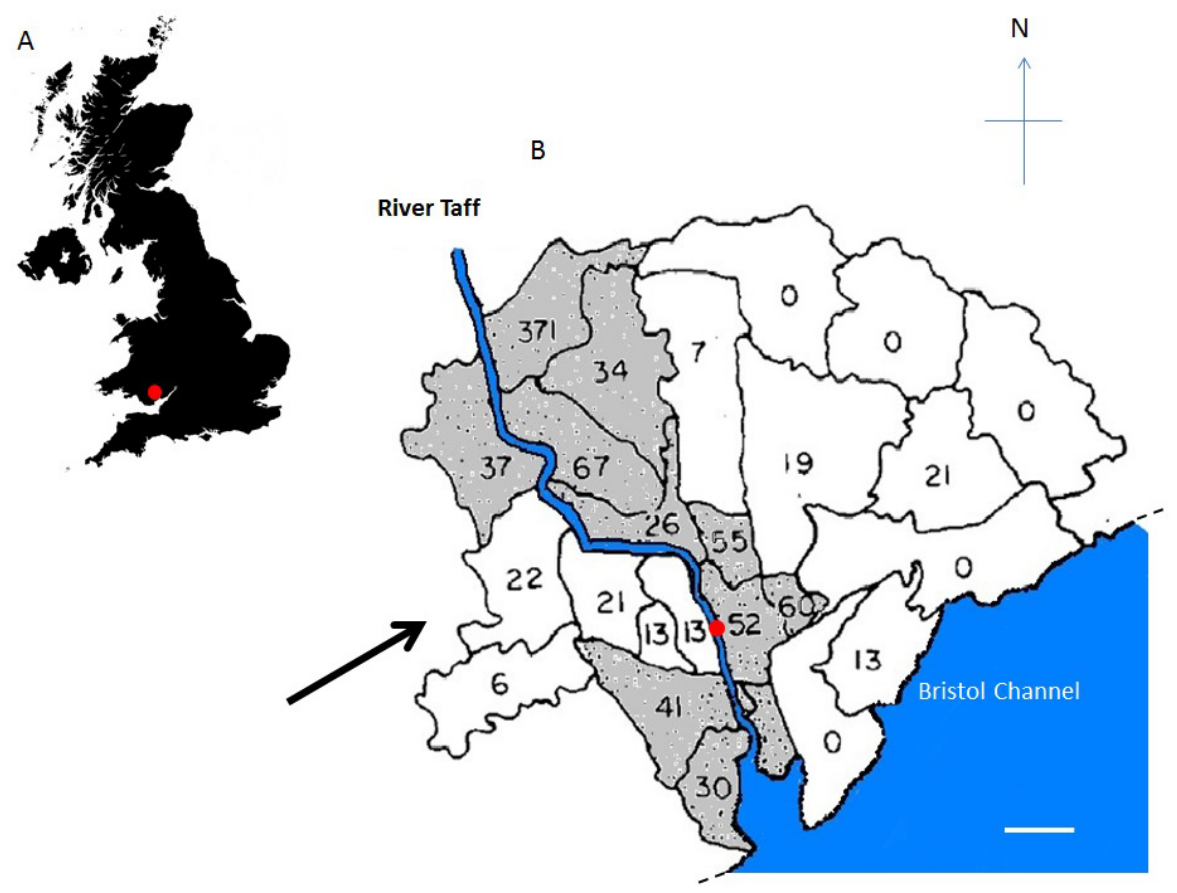

In the present study, we tested whether we could detect Map in aerosols originating from the River Taff, using a high volume impaction sampler (HVIS) designed for collecting particulate matter (PM 2.5-10; Figure 2) [35-37]. We also investigated domestic showers to find out whether they could 
be a source of exposure; thus seeking to extend the diverse routes for human exposure proposed by Pickup et al. [20].

Figure 2. Aerosol sampling using a high volume impaction system. (A) The system in place connected to a high volume vacuum pump (not shown); (B) the sampler showing the position of the four foam collection substrates; $(\mathbf{C})$ the foam placed in position over one of the slit nozzle cascade impactors (see arrow); (D) the foam removed from the slit nozzle cascade impactors (ii) showing collected particles from the sampler (i).

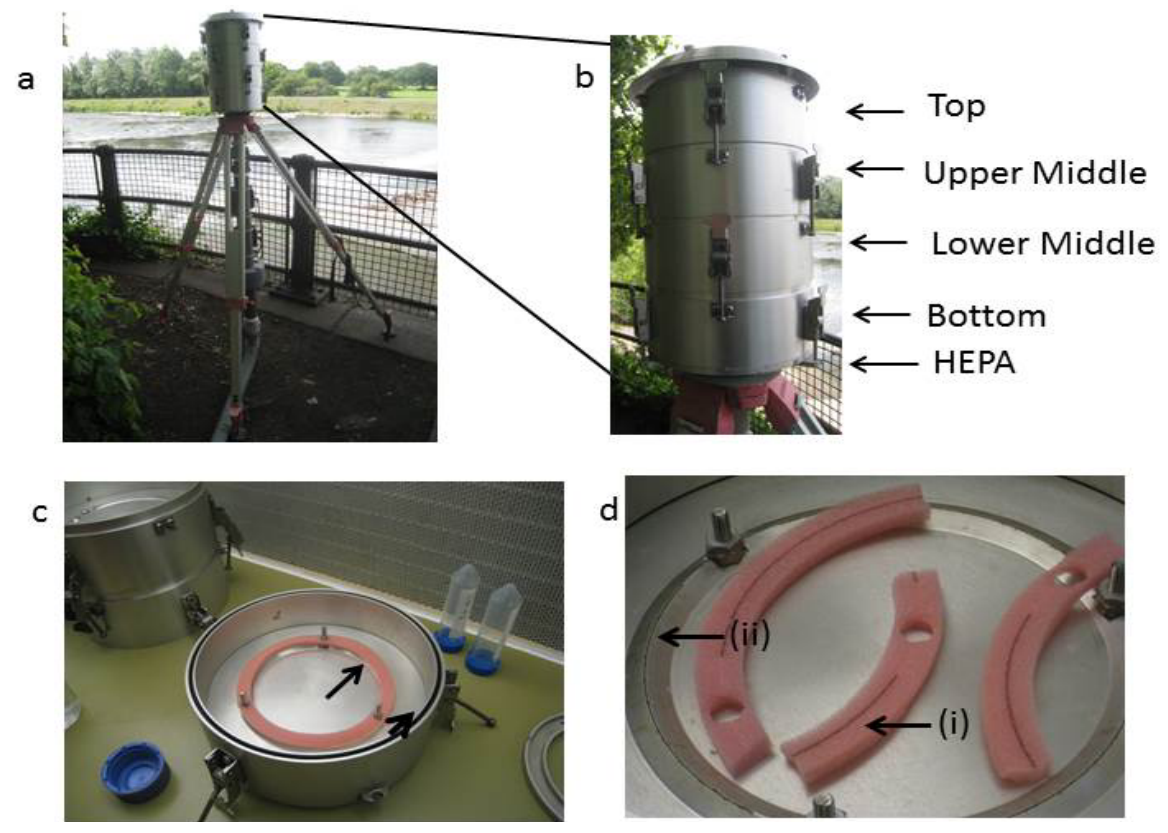

\section{Results}

\subsection{Aerosols}

\subsubsection{The Efficiency of Recovery of Bacteria from the Foam Collection Substrate}

This is the first study to make use of the HVIS for microbiological analysis. The foam collection substrate, originally designed for particulate matter (PM10) capture, was tested for ease of recovering culturable bacteria, as it was anticipated that there would be some cell loss due to adsorption and derived from the clumping associated with mycobacteria. In separate experiments, foams were infused with E. coli JM101 and M. immunogenum over a serial dilution range delivering cell numbers from 10-10 $0^{7} \mathrm{CFU} \mathrm{mL} \mathrm{m}^{-1}$ for E. coli and $10-10^{5} \mathrm{CFU} \mathrm{mL}^{-1}$ for M. immunogenum. For E. coli, the efficiency of recovery decreased with decreasing infusion concentration from approximately $200 \%$ (for $10^{6} / 10^{7} \mathrm{CFU} \mathrm{mL} \mathrm{m}^{-1}$ infusions, possibly due to cell multiplication at high cell density) to $69 \%-43 \%$ for an infused cell concentration in the range of $10-10^{5}$, respectively. No CFU were recovered when the foam was seeded with $10 \mathrm{CFU} \mathrm{mL}^{-1}$. M. immunogenum was infused in the range $10-10^{5} \mathrm{CFU} \mathrm{mL}^{-1}$ with CFU only being recovered from the $10^{5}$ cell infusion at an efficiency of $0.05 \%$. The detection of M. immunogenum by qPCR demonstrated variable recoveries of between $0.08 \%$ and $3.05 \%$ for the cell equivalent (CE) infusion range $10-10^{7}$, respectively, indicating better recovery at low cell density. No CE were detected by qPCR when initially infused below concentrations of $10^{1} \mathrm{CE} \mathrm{mL}^{-1}$. Overall 
results indicated that bacteria could be recovered from the foam collection substrate, originally designed for PM10 collection, but the efficiency of recovery is likely dependent on the concentration and cell type.

\subsubsection{Analysis of River Taff Foam Collection Substrates}

\subsubsection{Culture}

River aerosols were obtained on five occasions, with each filtering a total of $198 \mathrm{~m}^{3}$ of air per sampling session. Both heterotrophic plate counts and direct microscope counts were carried out on the bacteria recovered from the foam collection substrates located at the top, middle and bottom of the HVIS (Table 1; Figure 2).

Table 1. Assessment of the bacterial load of aerosols from the River Taff by epifluorescence microscopy and the culture of general heterotrophic bacteria. (Samples were collected between November, 2010, and September, 2011; ND, not determined).

\begin{tabular}{|c|c|c|c|}
\hline $\begin{array}{c}\text { Date } \\
(\mathrm{MM} / \mathrm{DD} / \mathrm{YY})\end{array}$ & Filter Level & $\begin{array}{c}\text { Culturable Counts (R2A Agar) } \\
\text { Mean CFUs m } \\
\text { (Standard Deviation) }\end{array}$ & $\begin{array}{l}\text { Direct Counts (DAPI) } \\
\text { Mean Cells m } \\
\text { (Standard Deviation) }\end{array}$ \\
\hline \multirow{4}{*}{ 11.09.10 } & Top & $1.11 \times 10^{4}\left( \pm 3.21 \times 10^{3}\right)$ & $1.89 \times 10^{5}\left( \pm 9.62 \times 10^{4}\right)$ \\
\hline & Upper Middle & $6.01 \times 10^{4}\left( \pm 1.17 \times 10^{4}\right)$ & $1.60 \times 10^{5}\left( \pm 6.27 \times 10^{4}\right)$ \\
\hline & Lower Middle & ND & ND \\
\hline & Bottom & $1.19 \times 10^{2}\left( \pm 1.06 \times 10^{2}\right)$ & ND \\
\hline \multirow{3}{*}{05.24 .11} & Top & $1.58 \times 10^{4}\left( \pm 8.17 \times 10^{32}\right)$ & $2.58 \times 10^{5}\left( \pm 1.47 \times 10^{5}\right)$ \\
\hline & Middle & ND & ND \\
\hline & Bottom & ND & ND \\
\hline \multirow{3}{*}{06.15 .11} & Top & $5.65 \times 10^{4}\left( \pm 2.56 \times 10^{4}\right)$ & ND \\
\hline & Middle & ND & ND \\
\hline & Bottom & ND & ND \\
\hline \multirow{4}{*}{08.17 .11} & Top & $5.86 \times 10^{4}\left( \pm 4.23 \times 10^{3}\right)$ & $5.20 \times 10^{7}\left( \pm 2.46 \times 10^{7}\right)$ \\
\hline & Upper middle & $1.27 \times 10^{5}\left( \pm 2.45 \times 10^{4}\right)$ & ND \\
\hline & Lower middle & $2.12 \times 10^{2}\left( \pm 9.68 \times 10^{1}\right)$ & ND \\
\hline & Bottom & 0 & ND \\
\hline \multirow{4}{*}{09.21 .11} & Top & $3.50 \times 10^{4}\left( \pm 2.19 \times 10^{4}\right)$ & $2.75 \times 10^{5}\left( \pm 1.64 \times 10^{5}\right)$ \\
\hline & Upper middle & $2.26 \times 10^{3}\left( \pm 1.73 \times 10^{2}\right)$ & $3.91 \times 10^{4}\left( \pm 1.16 \times 10^{4}\right)$ \\
\hline & Lower middle & $3.90 \times 10^{1}\left( \pm 5.08 \times 10^{\circ}\right)$ & ND \\
\hline & Bottom & 0 & ND \\
\hline
\end{tabular}

The foams collected bacteria in decreasing numbers from "top" to "bottom" in the mean range $6.01 \times 10^{4}$ to $3.90 \times 10^{1} \mathrm{CFU} \mathrm{m}^{-3}$ for culturable bacteria and in the mean range $5.2 \times 10^{7}$ to $3.91 \times 10^{4} \mathrm{CFU} \mathrm{m}{ }^{-3}$ for direct counts. There was no significant difference between the culturable numbers collected on the top and upper middle foams (mean $4.7 \times 10^{5} \pm 7.2 \times 10^{5} \mathrm{CFU} \mathrm{m}^{-3}$ ), but the difference in numbers between the top and lower middle and bottom were close to being significantly different $(p=0.06)$. Direct counts by microscopy for top and upper middle foams had a mean $8.8 \times 10^{7} \pm 2.1 \times 10^{8}$ cells $\mathrm{m}^{3}$, with no significant difference between top and upper middle foams. 
Therefore, the HVIS collected the majority of bacteria from the air passing over the river in the top and upper middle collection substrates.

\subsubsection{Molecular Analyses}

16S rrn gene amplification was successful from all top and upper middle section foams throughout the sampling period. The bottom sections were all negative. PCR detection was not observed in samples where general heterotrophs numbered $<10^{3} \mathrm{CFU} \mathrm{m}^{-3}$ (Table 2).

Table 2. PCR detection of eubacteria (16S rrn gene) Mycobacterium spp. (gMyc) and Map (IS900 and F57) in aerosol collection foams collected from November, 2010, to September, 2011 (CE, cell equivalents).

\begin{tabular}{|c|c|c|c|c|c|}
\hline $\begin{array}{c}\text { Date } \\
(\mathrm{MM} / \mathrm{DD} / \mathrm{YY})\end{array}$ & Filter Level & $\begin{array}{l}\text { Eubacterial } \\
16 S \text { rrn Gene }\end{array}$ & $\begin{array}{c}\text { Mycobacterium spp. } \\
\text { 16-23S rRNA ITS } \\
(\mathrm{gMyc})\left(\mathrm{CE} \mathrm{m}^{-3}\right)\end{array}$ & 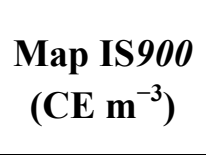 & 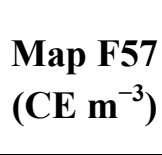 \\
\hline \multirow{4}{*}{11.09 .10} & Top & + & 0 & 0 & 0 \\
\hline & Upper Middle & + & 0 & $1-10$ & 0 \\
\hline & Lower middle & - & 0 & 0 & 0 \\
\hline & Bottom & - & 0 & 0 & 0 \\
\hline 05.24 .11 & Top & + & 0 & 0 & 0 \\
\hline 06.15 .11 & Top & + & 0 & 0 & 0 \\
\hline \multirow{4}{*}{08.17 .11} & Top & + & $1-10$ & 0 & 0 \\
\hline & Upper middle & + & 0 & 0 & 0 \\
\hline & Lower middle & - & 0 & 0 & 0 \\
\hline & Bottom & - & 0 & 0 & 0 \\
\hline \multirow{4}{*}{09.21 .11} & Top & + & 0 & 0 & 0 \\
\hline & Upper middle & + & 0 & 0 & 0 \\
\hline & Lower middle & - & 0 & 0 & 0 \\
\hline & Bottom & - & 0 & 0 & 0 \\
\hline
\end{tabular}

Mycobacterial spp. were detected using the gMyc genus-specific assay in the foam on one occasion (08.17.11; Table 2). Map was detected by PCR (IS900 only) on a different occasion (11.09.10) and was found in the upper middle filter. Map was not detected by the confirmatory, but less sensitive, F57 PCR on any occasion. In summary, bacteria were detected on collection foams by culture and direct counts; the extracted DNA was of sufficient quality for PCR, and Map was detected in one sample by IS900 PCR.

\subsection{Showers}

Samples from the biofilms in showers tubes and heads were obtained from 23 homes across four counties in the U.K. ((Cumbria, Lancashire, Merseyside and West Sussex; 30 samples in total); Table 3). 
Table 3. Detection of Mycobacterium spp. and Mycobacterium avium subspecies paratuberculosis in shower heads and tubes by culture and qPCR (ND, not determined; $\mathrm{H}$ represents a shower head being sampled from the same shower unit; $\mathrm{a}, \mathrm{b}$ represent different showers from the same house; and numbers represent different locations). MGIT, mycobacterial growth indicator tubes.

\begin{tabular}{|c|c|c|c|c|c|}
\hline \multirow[b]{2}{*}{$\begin{array}{c}\text { Sample } \\
\text { Location/Number }\end{array}$} & \multicolumn{2}{|c|}{ Microscopy and Culture } & \multicolumn{3}{|c|}{ qPCR } \\
\hline & $\begin{array}{c}\text { Direct Counts and } \\
\text { Standard Deviation. } \\
\left(\text { Cells } L^{-1}\right)\end{array}$ & $\begin{array}{c}\text { Mycobacterial } \\
\text { Culture (MGIT) }\end{array}$ & $\begin{array}{l}\text { Mycobacterium } \\
\text { spp. }\left(\mathrm{CE} \mathrm{L} \mathrm{L}^{-1}\right)\end{array}$ & $\begin{array}{l}\text { Map IS900 } \\
\left(\mathrm{CE} \mathrm{L} \mathrm{L}^{-1}\right)\end{array}$ & $\begin{array}{r}\text { Map F57 } \\
\left(\mathrm{CE} \mathrm{L} \mathrm{L}^{-1}\right)\end{array}$ \\
\hline Cumbria-1 & ND & ND & $10^{4}-10^{5}$ & 0 & 0 \\
\hline Cumbria-2H & ND & - & $10^{6}-10^{7}$ & 0 & 0 \\
\hline Cumbria-2 & ND & - & $10^{6}-10^{7}$ & 0 & 0 \\
\hline Cumbria-3 & ND & - & $10^{3}-10^{4}$ & 0 & 0 \\
\hline Cumbria-4 & ND & - & $10^{2}-10^{3}$ & 0 & 0 \\
\hline Cumbria-5 & ND & ND & 0 & 0 & 0 \\
\hline Cumbria-6 & ND & ND & 0 & 0 & 0 \\
\hline Lancashire-1 & ND & ND & $10^{3}-10^{4}$ & 0 & 0 \\
\hline Lancashire-2 & ND & ND & $10^{7}-10^{8}$ & $1-10$ & $\mathbf{0}$ \\
\hline Lancashire-3 & ND & - & $10^{7}-10^{8}$ & 0 & 0 \\
\hline Lancashire-4 & $7.95 \times 10^{8}\left( \pm 4.02 \times 10^{8}\right)$ & - & $10^{5}-10^{6}$ & 0 & 0 \\
\hline Lancashire-5 & ND & - & $10^{6}-10^{7}$ & 0 & 0 \\
\hline Lancashire-6 & ND & ND & $10^{8}-10^{9}$ & 0 & 0 \\
\hline Lancashire-7 & ND & + & $10^{6}-10^{7}$ & 0 & 0 \\
\hline Lancashire-8 & ND & - & $10^{3}-10^{4}$ & 0 & 0 \\
\hline Lancashire-9 & $1.91 \times 10^{9}\left( \pm 6.07 \times 10^{8}\right)$ & - & $10^{6}-10^{7}$ & 0 & 0 \\
\hline Lancashire-10 & $1.63 \times 10^{9}\left( \pm 5.05 \times 10^{8}\right)$ & + & $10^{7}-10^{8}$ & 0 & 0 \\
\hline Merseyside -1 & ND & - & $10^{8}-10^{9}$ & $10^{3}-10^{4}$ & $10^{1}-10^{2}$ \\
\hline Merseyside-2 & ND & - & $10^{7}-10^{8}$ & $10^{2}-10^{3}$ & $10^{2}-10^{3}$ \\
\hline Merseyside-3 & ND & - & $10^{7}-10^{8}$ & 0 & 0 \\
\hline West Sussex-1aH & ND & ND & $10^{7}-10^{8}$ & 0 & 0 \\
\hline West Sussex-1a & ND & ND & $10^{6}-10^{7}$ & 0 & 0 \\
\hline West Sussex-1bH & ND & - & $10^{6}-10^{7}$ & 0 & 0 \\
\hline West Sussex-1b & ND & + & $10^{7}-10^{8}$ & 0 & 0 \\
\hline West Sussex-2a & $1.64 \times 10^{9}\left( \pm 7.39 \times 10^{8}\right)$ & - & $10^{9}-10^{1 \circ}$ & 0 & 0 \\
\hline West Sussex-2b & $2.25 \times 10^{9}\left( \pm 1.02 \times 10^{9}\right)$ & - & $10^{4}-10^{5}$ & 0 & 0 \\
\hline West Sussex-3aH & ND & - & $10^{4}-10^{5}$ & 0 & 0 \\
\hline West Sussex-3a & ND & - & $10^{5}-10^{6}$ & 0 & 0 \\
\hline West Sussex-3b & ND & + & $10^{5}-10^{6}$ & 0 & 0 \\
\hline West Sussex-4H & ND & - & $10^{4}-10^{5}$ & 0 & 0 \\
\hline
\end{tabular}

Mycobacterium spp. were detected by qPCR in 28 (93\%) samples covering all geographical regions. Their numbers ranged from $10^{2} \mathrm{CE} \mathrm{L}^{-1}$ to $10^{9}-10^{10} \mathrm{CE} \mathrm{L}^{-1}$ with $>20$ samples containing more than $10^{2}-10^{3} \mathrm{CE} \mathrm{L}^{-1}$ mycobacteria. The presence of viable mycobacteria was also confirmed by culture (with confirmation of acid-fastness by Kinyoun staining) in four out of six samples tested (Table 3). Map was detected in three samples from Merseyside and Lancashire, two samples of which 
were also positive in a confirmatory F57 PCR. Furthermore, Map was only detected in samples carrying the higher $10^{7}-10^{8}$ general mycobacterial load (Table 3 ).

\subsection{Discussion}

This study employed culture and higher sensitivity qPCR assays to assess two routes of human exposure to Map via aerosols, as proposed by Pickup et al. [19,20], namely, those from rivers and domestic showers.

\subsubsection{River Aerosols}

Various types of collection devices are available, such as impingers with a low volume collection of 10-30 L min ${ }^{-1}$, although some have a capacity of approximately $1000 \mathrm{~L} \mathrm{~min}^{-1}[38,39]$. Both dry and liquid collection systems have limitations, such as short collection times, impaction problems and low volume collection $[38,40]$. Our river sampling strategy for aerosols employed a high volume impaction system (HVIS; commonly referred to as the Cardiff Super-Sucker), which is normally used to study PM10 in urban and rural areas [37]. To our knowledge, there is no dedicated apparatus to facilitate the specific detection of aerosolized bacteria in such large volumes. As such, it was necessary to show the applicability of the HVIS system to the capture and recovery of bacteria in the present study. We demonstrated the use of the apparatus and showed that viable bacteria can be recovered from River Taff aerosols by culturing bacteria from $198 \mathrm{~m}^{3}$ air samples collected on each deployment. This recovery occurred despite the harsh physical and physiological conditions that the unit imposes on the bacteria and the non-standard collection foams used. The HVIS was placed near a weir, where the physical disturbance of the river would probably increase our chances of collecting aerosols.

Map was detected by IS900 qPCR, on one out of five sampling occasions, albeit in the range of 1-10 CE $\mathrm{m}^{3}$, but not by the less sensitive F57 PCR, which is consistent with the estimated Map numbers detected. In a previous qualitative study (presence/absence PCR; [19]), Pickup et al. (2005) sampled the river Taff waters for one year and reported that $32 \%$ of river samples at a location $1 \mathrm{~km}$ upstream from the present site were positive for Map [19]. The 2005 study [19] was the result of a feasibility study comprising seven ad hoc sampling sessions, previously spread out over several months. Map was detected in only one of those seven samples. However, its detection led to the more intensive sampling regime that was later reported [19]. We subsequently showed that the ad hoc feasibly study returned a low Map-positive rate because the bacterium is transported in the river in pulses driven by rainfall and that there are periods where Map is not detected [19,20], and we sampled on all, but one, of those occasions. The conclusions of the present study mirror that of our previous studies $[19,20,41]$ in that sampling and detection methods likely underestimate actual Map numbers. More specifically, previous experience from ad hoc sampling and Map screening followed by more intense and frequent assessments in 2005 suggest that if we were able to collect aerosol samples on a twice weekly basis at the present sampling site, then our model for the River Taff would suggest a higher detection of Map in aerosol samples [19]. This is our intention in future studies.

Both the ability of aerosol droplets to concentrate bacteria and the spread of mycobacteria in aerosols are well documented [23,42-47]. More specifically, Map has been detected in aerosols in cattle barns and within the farm environment [48-51] and has been identified as a possible route for 
infection for Johne's disease in cattle [52]. Although limited in scope and resolution, our feasibility study is the first to show that Map is airborne in non-farm environments, namely in aerosols emanating from rivers, and its presence fits the criteria in our understanding of the Map loading of rivers and its transportation drivers from the catchment [19].

This study also gives credence to our suggestion that the epidemiology of Crohn's patients in Cardiff (UK) is affected by aerosols, due to the significant association with the river and the prevailing wind direction [19]. The study by Mayberry and Hitchens [35] examined the distribution of Crohn's disease patients in Cardiff based on age, sex, religion, smoking, drinking and drug taking with no statistical difference within and between these parameters [35]. They found, however, that CD patients appeared in highly significant clusters and that these were closely associated with the course of the River Taff with larger concentrations of CD nearer the source mouth (Tiger Bay). Mayberry and Hitchens [35] suggested that environmental factors associated with the river may contribute to the disease distribution. We suggest that, although more study is needed, aerosols might be the missing factor suggested by Mayberry and Hitchens [35,36,53,54] and ourselves [19]. Taken together with our present results and those that show that Map is significantly associated with Crohn's disease $[8,10]$, these data suggest that the pattern of clustering of Crohn's disease in Cardiff may have been due to the long-term inhalation of M. avium subsp. paratuberculosis from the River Taff.

\subsubsection{Shower Heads}

Furthermore, water is abstracted from rivers for domestic use. Given the widespread geographical distribution of Map [41] and its presence in water ways [19,20,24], it is not surprising that the delivery of domestic water supply may prove an issue. Mycobacteria have been found in drinking water [21,22,29], and pathogens, including mycobacteria, have been found in showerheads [27,29]. Furthermore, non-tuberculous mycobacteria (NTM) and other opportunistic human pathogens were enriched to high levels in many showerhead biofilms [27]. These authors concluded that showerheads may present a significant potential exposure to aerosolized microbes, including documented opportunistic pathogens. Our results support this with qPCR, showing 28 of 30 (93\%) samples to be positive for Mycobacterium spp. in a range from $10^{2}-10^{10} \mathrm{CE} \mathrm{L}^{-1}$. Additionally, we report for the first time the specific detection Map in shower tubes in numbers from $10^{1}-10^{4} \mathrm{CE} \mathrm{L}^{-1}$ with two samples confirmed as Map-positive by both IS 900 and F57 PCR and one other unconfirmed Map-positive in which IS900 was detected solely $\left(1-10 \mathrm{CE} 1^{-1}\right)$. The presence in the shower tube will result in frequent sloughing from the surface of the biofilm, resulting in the appearance of Mycobacterium spp. and Map in shower water and the potential for subsequent inhalation via shower-generated aerosols as suggested by Feazel et al. [27].

\section{Experimental Section}

\subsection{Bacterial Strains and Culture}

Escherichia coli strain JM101 was maintained on nutrient agar and cultured overnight at $30{ }^{\circ} \mathrm{C}$ in nutrient broth (Oxoid, UK) with shaking at $180 \mathrm{rpm}$. General heterotrophs were cultured at $30{ }^{\circ} \mathrm{C}$ on solid R2A medium (Oxoid, UK) for 48 h. Mycobacterium immunogenum ATCC $700505^{\mathrm{T}}$ was cultured at $30{ }^{\circ} \mathrm{C}$ for up to 1 week on Middlebrook $7 \mathrm{H} 10$ agar supplemented with OADC $(10 \% \mathrm{v} / \mathrm{v})$ and 
glycerol $(5 \% \mathrm{v} / \mathrm{v})$ (BD Biosciences, Oxford, UK) or in mycobacterial growth indicator tubes (MGITs), supplemented with OADC (10\% v/v) [54]. Mycobacterium avium subsp. paratuberculosis K-10 (Map) and general mycobacteria from shower samples were cultured in the same way, but with the addition of polymyxin B sulphate $\left(100 \mu \mathrm{g} \mathrm{mL}^{-1}\right)$, cycloheximide $\left(25 \mu \mathrm{g} \mathrm{mL}^{-1}\right)$ and mycobactin $\mathrm{J}\left(2 \mu \mathrm{g} \mathrm{mL}^{-1}\right)$; and increased incubation times of up to 6 months (Map culture only).

\subsection{Sampling Sites}

Aerosol sampling took place from the east bank on the River Taff at Blackweir, Bute Park Cardiff (GBOS ST170780), between November, 2010, and September, 2011. Shower samples were taken from a number of houses across England during the period 2011-2013.

\subsection{Shower Sampling}

Domestic shower samples were obtained by removal of the shower hose from the shower unit and shower head and emptied of standing water. Sterile glass beads (1 g; $5 \mathrm{~mm}$ in diameter) in $10 \mathrm{~mL}$ sterile $1 \times$ PBS were poured into the pipe. The ends were sealed with alcohol-washed parafilm (Bemis Ltd, UK), and the pipe was manually shaken for $2 \mathrm{~min}$ to remove the internal biofilm. The contents were poured into a sterile McCartney bottle, sealed and put on ice prior to transport and processing: the culture of mycobacteria (Section 3.3.1), direct counts by microscopy (Section 3.5) and qPCR (Section 3.6 and 3.7). Counts obtained from 5-mL samples were converted to cells $\mathrm{L}^{-1}$ or $\mathrm{CE} \mathrm{L}^{-1}$.

\subsubsection{Recovery of Mycobacteria from Shower Biofilms}

For the recovery of mycobacteria from shower samples, $5 \mathrm{~mL}$ of the sample obtained above was centrifuged for $30 \mathrm{~min}$ at $4000 \times \mathrm{g}$. Samples were then decontaminated to favour the growth of robust mycobacteria, whilst eradicating other bacteria and fungi. Concentrated shower samples were re-suspended in $1 \mathrm{~mL} 0.7 \%$ hexadecylpyridinium chloride and incubated at room temperature for $1 \mathrm{~h}$. This was followed by centrifugation for $30 \mathrm{~min}$ at $4000 \times \mathrm{g}$ and re-suspension in $500 \mu \mathrm{L}$ sterile PBS. Two hundred microlitres of this sample were then inoculated into MGITs and $100 \mu \mathrm{L}$ onto $7 \mathrm{H} 10$ solid medium in triplicate, as described above. Mycobacterial growth either as colonies on solid media or from clumped cells in MGITs was confirmed by checking for both acid fastness by Kinyoun staining (as per the manufacturer's instructions; Becton Dickinson Diagnostics, Oxford, UK) and DNA extraction followed by quantitative real-time PCR (qPCR) using the Mycobacterium genus-specific assay described below.

\subsection{Aerosol Sampling}

\subsubsection{Collection}

Aerosol collection was carried out using a high-volume (low cut-off; 1100-1/min) impaction system (HVIS; Figure 2) linked to a $240 \mathrm{~V}$ voltage high performance vacuum pump [37,55]. The HVIS comprised a series of multistage round slit nozzle cascade impactors, which direct incoming air through four sterile polyurethane foam collection substrates labelled by position within the unit (top, 
upper and lower middle and bottom) [56,57] (Figure 2a,b). The HVIS was configured to collect particles in the ranges $10-2.5 \mu \mathrm{m}$ and $2.5-0.1 \mu \mathrm{m}$, with the size being determined by the slit nozzles rather than the collection substrate [56] (Figure 2b). The HVIS was run for $3 \mathrm{~h}$ on the opposite river bank to the prevailing wind. Upon return to the laboratory, the multistage impactors were disassembled aseptically in a microbiological safety cabinet (Figure 2c), the circular foam collection substrates removed, cut into quarters using sterile scissors and placed at $-80{ }^{\circ} \mathrm{C}$ in sterile plastic $50-\mathrm{mL}$ centrifuge tubes (Figure 2d) until required. Each of the collection foams was processed separately. They were then aseptically transferred to stomacher bags and $20 \mathrm{~mL}$ sterile $1 \times$ PBS and placed in the stomacher (Stomacher ${ }^{\circledR} 80$ Biomaster; Seward Ltd., Worthing, UK). Stomaching was performed at the "high speed" setting (300 rpm $\pm 5 \%)$ for $5 \mathrm{~min}$ at room temperature. The total volume of this suspension was then decanted into sterile $50 \mathrm{~mL}$ tubes and cells concentrated to $1 \mathrm{~mL}$ by centrifugation $16,000 \times \mathrm{g}$ for $10 \mathrm{~min}$ at room temperature. This final suspension was then used for culture and DNA extraction for qPCR estimates of cell numbers of mycobacteria and MAP.

\subsubsection{Controlled Assessment of the Efficiency of Cell Recovery from Foam Substrates}

To test the efficiency of recovery of cells foam substrates used in the HVIS aerosol collector, substrates were infused with E. coli JM101 (to give a representative sample of a fast growing general heterotrophy) and with $M$. immunogenum (a fast growing non-tuberculous mycobacterium, which aggregates into cell clumps, typical of mycobacteria). Foam substrates were cut into 1-cm strips and sterilised by autoclaving prior to use. Sterile foams were then placed into sterile 1.5-mL Eppendorf tubes and infused with $100 \mu \mathrm{L}$ of cell suspension. This volume had previously been shown to be fully retained by the foam (not shown). Cultures of E. coli JM101 and M. immunogenum were grown to approximate cell concentrations of $10^{8} \mathrm{~mL}^{-1}$ before centrifugation for 3 minutes at $3000 \times \mathrm{g}$ and re-suspension in sterile $1 \times$ PBS. Separate cell suspensions of each culture were serially diluted to $10^{-7}$ in $1 \times$ PBS to provide an estimate of how the efficiency of recovery changed across a range of concentrations. Infused foams were undisturbed for $1 \mathrm{~h}$ at room temperature. They were then aseptically transferred to stomacher bags and processed as described previously. The final suspension was then used for culture and DNA extraction for qPCR estimates of cell numbers. E. coli and $M$. immunogenum were cultured as above, and the efficiency of cell recovery was determined by comparing the colony forming units $\mathrm{CFU} \mathrm{mL} \mathrm{m}^{-1}$ (or cell equivalents, see below) recovered to that of the original cultures used for infusion. Due to cell clumping that affects mycobacterial CFU counts, M. immunogenum cell equivalents [55] were also assessed by qPCR, as described below.

\subsection{Direct Microscope Counts}

Direct counts were carried out using DAPI staining [58] using a Leitz labarlux S epifluorescence microscope at $\times 1250$ magnification under UV excitation at $358 \mathrm{~nm}$ and emission at $430 \mathrm{~nm}$.

\subsection{DNA Extraction}

Total nucleic acids were extracted from all samples using the MagMax total nucleic acid extraction kit (P/N AM1840, Life Technologies, Paisley, UK) according to manufacturer's instructions, apart 
from replacement of kit-supplied carrier nucleic acid with molecular reagent water (Sigma Aldrich Ltd., Poole, UK). Cell lysis by bead beating was performed on a FastPrep ${ }^{\circledR}-24$ instrument (MP Biomedicals, Loughborough, UK) for 2 cycles of $1 \mathrm{~min}$ at a speed of $6.5 \mathrm{~m} / \mathrm{s}$ (with $5 \mathrm{~min}$ at room temperature in between cycles). All samples were processed in sterile 1.5-mL microcentrifuge tubes. Nucleic acid extractions were also performed with $200 \mu \mathrm{L}$ of PCR water (Sigma Aldrich Ltd., Poole, UK) as a negative control. DNA quality and concentration were determined using a Nanodrop 8000 spectrophotometer (Labtech International Ltd., Ukfield, UK). Finally, all total nucleic acids were stored at $-80^{\circ} \mathrm{C}$.

\subsection{PCR Amplification and $q P C R$}

End-point PCR amplification was carried out using a Veriti thermal cycler (P/N 4375786, Life Technologies) in MicroAmp 96-well thin-walled reaction plates (P/N 4346906, Life Technologies). Amplification of the $16 \mathrm{~S} r r n$ gene was carried out using primers $\mathrm{pE}$ and $\mathrm{pH}$ ' [59]; Table 4). Reactions $(20 \mu \mathrm{L})$ were performed using and in strict accordance with the instructions provided with the AmpliTaq Gold 360 Master Mix system (P/N 4398881, Life Technologies).

Table 4. PCR primers and hydrolysis probes used in this study. * Our designation as oligonucleotides were originally simply the forward and reverse primer Taqman probe when described in van Coppenraet et al. (2004).

\begin{tabular}{|c|c|c|c|}
\hline Oligonucleotide & Sequence and Fluorophore/Quencher $\left(5^{\prime} \rightarrow 3^{\prime}\right)$ & Target Gene & Reference \\
\hline $\mathrm{pE}$ (forward) & AAACTCAAAGGAATTGACGG & Eubacterial 16S rrn gene & \multirow{2}{*}{ [59] } \\
\hline $\mathrm{pH}^{\prime}$ (reverse) & AAGGAGGTGATCCAGCCGCA & Eubacterial $16 \mathrm{~S} r r n$ gene & \\
\hline MimmFP (forward) & TTGATGTGCAGACGGATTCC & M. immunogenum rроB & \multirow{3}{*}[55]{} \\
\hline MimmRP (reverse) & CAACCTCGCGCCAACG & M. іттиповепит гров & \\
\hline $\begin{array}{c}\text { MimmTP } \\
\text { (hydrolysis probe) }\end{array}$ & $\begin{array}{c}\text { VIC-TTGAATGGTTGGTCGGCTCGCC- } \\
\text { TAMRA }\end{array}$ & M. iтmиповепит гроB & \\
\hline $\begin{array}{l}\text { gMycFP * } \\
\text { (forward) }\end{array}$ & GGGGTGTGGTGTTTGAG & $\begin{array}{c}\text { Mycobacterium genus } 16 \mathrm{~S}-23 \mathrm{~S} \\
\text { rrn gene ITS }\end{array}$ & \multirow{3}{*}[60]{} \\
\hline $\begin{array}{l}\text { gMycRP * } \\
\text { (reverse) }\end{array}$ & CTCCCACGTCCTTCATC & $\begin{array}{c}\text { Mycobacterium genus } 16 \mathrm{~S}-23 \mathrm{~S} \\
\text { rrn gene ITS }\end{array}$ & \\
\hline $\begin{array}{c}\mathrm{gMycP} * \\
\text { (hydrolysis probe) }\end{array}$ & $\begin{array}{l}\text { 6FAM-TGGATAGTGGTTGCGAGCATC- } \\
\text { TAMRA }\end{array}$ & $\begin{array}{l}\text { Mycobacterium genus } 16 \mathrm{~S}-23 \mathrm{~S} \\
\text { rrn gene ITS }\end{array}$ & \\
\hline $\begin{array}{l}\text { IS900qPCRF } \\
\text { (forward) }\end{array}$ & GATGGCCGAAGGAGATTG & $\begin{array}{l}\text { M. avium subsp. } \\
\text { paratuberculosis IS } 900\end{array}$ & \multirow{3}{*}{ [61] } \\
\hline $\begin{array}{l}\text { IS900qPCRR } \\
\text { (reverse) }\end{array}$ & CACAACCACCTCCGTAACC & $\begin{array}{l}\text { M. avium subsp. } \\
\text { paratuberculosis IS } 900\end{array}$ & \\
\hline $\begin{array}{l}\text { IS900qPCRTM } \\
\text { (hydrolysis probe) }\end{array}$ & $\begin{array}{l}\text { 6FAM- } \\
\text { ATTGGATCGCTGTGTAAGGACACGT-BHQ }\end{array}$ & $\begin{array}{c}\text { M. avium subsp. } \\
\text { paratuberculosis IS } 900 \\
\end{array}$ & \\
\hline F57-F (forward) & TACGAGCACGCAGGCATTC & $\begin{array}{l}\text { M. avium subsp. } \\
\text { paratuberculosis F57 }\end{array}$ & \multirow{3}{*}{ [62] } \\
\hline F57-R (reverse) & CGGTCCAGTTCGCTGTCAT & $\begin{array}{l}\text { M. avium subsp. } \\
\text { paratuberculosis F57 }\end{array}$ & \\
\hline $\begin{array}{l}\text { F57 Taqman } \\
\text { (hyd } \\
\text { (hydrolysis probe) }\end{array}$ & VIC-CCTGACCACCCTTC-MGB & $\begin{array}{c}\text { M. avium subsp. } \\
\text { paratuberculosis F57 }\end{array}$ & \\
\hline
\end{tabular}


Where practicable, all real-time quantitative PCR amplifications were performed and reported in accordance with the MIQE guidelines [62]. Amplifications were carried out in a 7500 FAST Real-Time PCR system (Life Technologies, Paisley, UK) in MicroAmp optical reaction plates (P/N N801-0560, Life Technologies). Primers and hydrolysis probes specific to each of Mycobacterium immunogenum, Mycobacterium spp. and Map are listed in Supplementary Table 1.

Map was detected by qPCR using single-tube duplex reactions that combined the previously described assays [61,62] to amplify Map-specific regions IS900 and F57, respectively. These assays comprised primers and hydrolysis probes described in Supplementary Table 1. Primer and probe concentrations were optimized such that each reaction $(20 \mu \mathrm{L})$ contained the following: $10 \mu \mathrm{L}$ of $2 \times$ Environmental Master Mix (P/N 4396838, Life Technologies, UK); $1 \mu \mathrm{L}(300 \mathrm{nM})$ of each primer $(\mathrm{P} / \mathrm{N}$ 4304972, Life Technologies, UK) and $1 \mu \mathrm{L}(250 \mathrm{nM})$ of each probe $(\mathrm{P} / \mathrm{N}$ 450003, Life Technologies, UK); $2 \mu \mathrm{L}$ of sterile PCR grade water (Sigma-Aldrich, UK); and $2 \mu \mathrm{L}$ DNA. No template controls received sterilized PCR-grade water instead of DNA. The following cycling profile was used: one cycle of $95^{\circ} \mathrm{C}$ for $10 \mathrm{~min}$ (for the activation of the AmpliTaq Gold enzyme) and 45 cycles of $95{ }^{\circ} \mathrm{C}$ for $15 \mathrm{~s}$ and $60^{\circ} \mathrm{C}$ for $1 \mathrm{~min}$. DNA used in standard curves was quantified and standard curves constructed in accordance with methods outlined in Rhodes et al., (2008), based upon a genome size of $4.83 \mathrm{Mbp}$ for $M$. avium ssp. paratuberculosis K-10 (GenBank Accession No. NC002944) and an average number of gene copies per genome of 17 (IS900) and 1 (F57) [63,64]. The sensitivity of the IS900 and F57 assays was determined for the present study using serially-diluted Map K-10 DNA. The limit of detection of the combined duplex assay of IS900 and F57 was 20-50 cell equivalents (CE; see [55]). All reactions were carried out in triplicate. Inhibition of the PCR reaction was tested in a separate round of reactions after the initial MAP assessments by the addition of $2 \mathrm{ng}$ of Map K-10 DNA (approximately $4 \times 10^{5}$ genomes) to all samples and to control reactions where no sample DNA was added. No amplification, or a shift to a higher quantification cycle (Cq) value [65] when compared with the control reactions, was interpreted as inhibition.

\section{Conclusions}

Both river aerosol and shower unit results presented here are consistent with inhalation as a probable exposure route of M. avium subsp. paratuberculosis and other non-Map mycobacterial infections. Inhalation has been shown as a route for the infection of cattle $[49,66]$. M. avium subsp. avium demonstrates selective binding to pulmonary surfactant proteins [67]. Lung involvement is well described in adults with Crohn's disease [67,68], and the disease in children often begins with a cough and a mild granulomatous tracheobronchitis [69-73]. Initial invasion via the oral route followed by Map's substantial tissue tropism for the gut may result in chronic inflammation of the intestine [74,75]. Although Map is difficult to detect and even more difficult to culture, recent data has shown it to be significantly associated with Crohn's disease and, if appropriate culture and PCR tests are done correctly, that almost everyone with chronic inflammation of the gut of the Crohn's disease type is found to be infected with this chronic enteric pathogen [8,10,76-80]. Delivery of Map from showers and river aerosols may provide two previously undescribed human exposure routes for the pathogen significantly associated with Crohn's disease. 


\section{Acknowledgments}

We wish to thank Natural Environment Research Council (Grant NE/F014791/1) and the NHS Grant (BLS7044; Hollian Richardson) for support and Dr. Tim Jones (Cardiff University) for the loan of the HVIS.

\section{Author Contributions}

R.P. wrote the paper. R.P., G.R., J. H.-T. and A.H. designed the experiments. R.P., A.W., H.R. and G.R. carried out the field work. H.R. performed the experiments. G.R., H.R., A.W., J. H.-T. and A.H. helped improve the manuscript.

\section{Conflicts of Interest}

The authors declare no conflict of interest.

\section{References}

1. Thorel, M.F.; Krichevsky, M.; Levyfrebault, V.V. Numerical taxonomy of mycobactin-dependent mycobacteria, emended description of Mycobacterium avium, and description of Mycobacterium avium subsp avium subsp-nov, Mycobacterium avium subsp paratuberculosis subsp-nov, and Mycobacterium avium subsp silvaticum subsp-nov. Int. J. Syst. Bact. 1990, 40, 254-260.

2. Chacon, O.; Bermudez, L.E.; Barletta, R.G. Johne's disease, inflammatory bowel disease, and Mycobacterium paratuberculosis. A. Rev. Microbiol. 2004, 58, 329-363.

3. Nielsen, S.S.; Toft, N. A review of prevalences of paratuberculosis in farmed animals in Europe. Prev. Vet. Med. 2009, 88, 1-14.

4. Buergelt, C.D.; Hall, C.; McEntee, K.; Duncan, J.R. Pathological evaluation of para-tuberculosis in naturally infected cattle. Vet. Path. 1978, 15, 196-207.

5. Over, K.; Crandall, P.G.; O’Bryan, C.A.; Ricke, S.C. Current perspectives on Mycobacterium avium subsp. paratuberculosis, johne's disease, and crohn's disease: A review. Crit. Rev. Microbiol. 2011, 37, 141-156.

6. Clarke, C.J. The pathology and pathogenesis of paratuberculosis in ruminants and other species. J. Comp. Pathol. 1997, 116, 217-261.

7. McClure, H.M.; Chiodini, R.J.; Anderson, D.C.; Swenson, R.B.; Thayer, W.R.; Coutu, J.A. Mycobacterium-paratuberculosis infection in a colony of stumptail macaques (Macaca arctoides). J. Infect. Dis. 1987, 155, 1011-1019.

8. Feller, M.; Huwiler, K.; Stephan, R.; Altpeter, E.; Shang, A.; Furrer, H.; Pfyffer, G.E.; Jemmi, T.; Baumgartner, A.; Egger, M. Mycobacterium avium subspecies paratuberculosis and crohn's disease: A systematic review and meta-analysis. Lancet Infect. Dis. 2007, 7, 607-613.

9. Chiodini, R.J.; Chamberlin, W.M.; Sarosiek, J.; McCallum, R.W. Crohn's disease and the mycobacterioses: A quarter century later. Causation or simple association? Crit. Rev. Microbiol. 2012, 38, 52-93.

10. Bull, T.J.; McMinn, E.J.; Sidi-Boumedine, K.; Skull, A.; Durkin, D.; Neild, P.; Rhodes, G.; Pickup, R.; Hermon-Taylor, J. Detection and verification of Mycobacterium avium subsp. 
paratuberculosis in fresh ileocolonic mucosal biopsy specimens from individuals with and without crohn's disease. J. Clin. Microbiol. 2003, 41, 2915-2923.

11. Larsen, J.W.A.; Ware, J.K.W.; Kluver, P. Epidemiology of bovine Johne's disease (bjd) in beef cattle herds in australia. Aust. Vet. J. 2012, 90, 6-13.

12. Olsen, I.; Siguroardottir, O.G.; Djonne, B. Paratuberculosis with special reference to cattle-A review. Vet. $Q$ 2002, 24, 12-28.

13. Sorensen, O.; Rawluk, S.; Wu, J.; Manninen, K.; Ollis, G. Mycobacterium paratuberculosis in dairy herds in alberta. Can. Vet. J 2003, 44, 221-226.

14. United States Department of Agriculture. Johne's disease on U. S. Dairies, 1991-2007. Available online: http://www.aphis.usda.gov/animal_health/nahms/dairy/downloads/dairy07/Dairy07_is_Johnes.pdf (accessed on 11 July 2014).

15. Department of the Environment, Food and Rural Affairs (UK). An Integrated Strategy to Determine the Herd Level Prevalence of Johne's Disease in the uk Dairy Herd. Available online: http://archive.defra.gov.uk/foodfarm/farmanimal/diseases/atoz/documents/johnes-report0911.pdf (accessed on 11 July 2014).

16. Caldow, G.; Strain, S.A.J.; Chapman, Z.; Kemp, R.; Cook, A.J. A survey to estimate the herd level prevalence of paratuberculosis in the dairy herd of the united kingdom. Cattle Pract. 2007, 15, 169-171.

17. Whittington, R.J.; Marsh, I.B.; Reddacliff, L.A. Survival of Mycobacterium avium subsp. paratuberculosis in dam water and sediment. Appl. Environ. Microbiol. 2005, 71, 5304-5308.

18. Larsen, A.B.; Merkal, B.S.; Vardaman, T.H. Survival time of Mycobacterium paratuberculosis. Am. J. Vet. Res. 1956, 17, 549-551.

19. Pickup, R.W.; Rhodes, G.; Arnott, S.; Sidi-Boumedine, K.; Bull, T.J.; Weightman, A.; Hurley, M.; Hermon-Taylor, J. Mycobacterium avium subsp. paratuberculosis in the catchment area and water of the river taff in south wales, united kingdom, an its potential relationship to clustering of crohn's disease cases in the city of cardiff. Appl. Environ. Microbiol. 2005, 71, 2130-2139.

20. Pickup, R.W.; Rhodes, G.; Bull, T.J.; Arnott, S.; Sidi-Boumedine, K.; Hurley, M.; Hermon-Taylor, J. Mycobacterium avium subsp. paratuberculosis in lake catchments, in river water abstracted for domestic use, and in effluent from domestic sewage treatment works: Diverse opportunities for environmental cycling and human exposure. Appl. Environ. Microbiol. 2006, 72, 4067-4077.

21. Beumer, A.; King, D.; Donohue, M.; Mistry, J.; Covert, T.; Pfaller, S. Detection of Mycobacterium avium subsp. paratuberculosis in drinking water and biofilms by quantitative pcr. Appl. Environ. Microbiol. 2010, 76, 7367-7370.

22. Klanicova, B.; Seda, J.; Slana, I.; Slany, M.; Pavlik, I. The tracing of mycobacteria in drinking water supply systems by culture, conventional, and real time pcrs. Curr. Microbiol. 2013, 67, 725-731.

23. Falkinham, J.O. Ecology of nontuberculous mycobacteria-where do human infections come from? Preface. Sem. Resp. Crit. Care 2013, 34, 95-102.

24. Aboagye, G.; Rowe, M.T. Occurrence of Mycobacterium avium subspecies paratuberculosis in raw water and water treatment operations for the production of potable water. Wat. Res. 2011, 45, 3271-3278. 
25. Gill, C.O.; Saucier, L.; Meadus, W.J. Mycobacterium avium subsp paratuberculosis in dairy products, meat, and drinking water. J. Fd Prot. 2011, 74, 480-499.

26. Hruska, K.; Kaevska, M. Mycobacteria in water, soil, plants and air: A review. Vete. Med. 2012, 57, 623-679.

27. Feazel, L.M.; Baumgartner, L.K.; Peterson, K.L.; Frank, D.N.; Harris, J.K.; Pace, N.R. Opportunistic pathogens enriched in showerhead biofilms. P. Natl. Acad. Sci. USA 2009, 106, 16393-16398.

28. Thomson, R.; Tolson, C.; Carter, R.; Coulter, C.; Huygens, F.; Hargreaves, M. Isolation of nontuberculous mycobacteria (ntm) from household water and shower aerosols in patients with pulmonary disease caused by ntm. Am. J. Clin. Microb. 2013, 51, 3006-3011.

29. Falkinham, J.O., III; Iseman, M.D.; de Haas, P.; van Soolingen, D. Mycobacterium avium in a shower linked to pulmonary disease. J. Water Health 2008, 6, 209-213.

30. Gunesh, S.; Thomas, G.A.O.; Williams, G.T.; Roberts, A.; Hawthorne, A.B. The incidence of crohn's disease in cardiff over the last 75 years: An update for 1996-2005. Aliment. Pharm. Therap. 2008, 27, 211-219.

31. Gunesh, S.K.; Hawthorne, B.A.; Thomas, G.A.O.; Williams, G.T.; Roberts, A. Incidence of crohn's disease still rising in cardiff: 1931-2005. Gut 2007, 56, A110-A111.

32. Yapp, T.R.; Stenson, R.; Thomas, G.A.O.; Lawrie, B.W.; Williams, G.T.; Hawthorne, A.B. Crohn's disease incidence in cardiff from 1930: An update for 1991-1995. Eur. J. Gastroen. Hepat. 2000, 12, 907-911.

33. Thomas, G.A.O.; Millarjones, D.; Rhodes, J.; Roberts, G.M.; Williams, G.T.; Mayberry, J.F. Incidence of crohn's-disease in cardiff over 60 years-1986-1990 an update. Eur. J. Gastroen. Hepat. 1995, 7, 401-405.

34. Rose, J.D.R.; Roberts, G.M.; Williams, G.; Mayberry, J.F.; Rhodes, I. Cardiff crohns-disease jubilee-The incidence over 50 years. Gut 1988, 29, 346-351.

35. Mayberry, J.F.; Hitchens, R.A.N. Distribution of crohn's disease in cardiff. Soc. Sci. Med. 1978, 12, 137-138.

36. Mayberry, J.F. Recent epidemiology of ulcerative colitis and crohn's disease in cardiff. Int. J. Colorect. Dis. 1989, 4, 39-46.

37. Jones, T.; Moreno, T.; BeruBe, K.; Richards, R. The physicochemical characterisation of microscopic airborne particles in south wales: A review of the locations and methodologies. Sci. Total. Environ. 2006, 360, 43-59.

38. Xu, Z.; Wu, Y.; Shen, F.; Chen, Q.; Tan, M.; Yao, M. Bioaerosol science, technology, and engineering: Past, present, and future. Aerosol. Sci. Tech. 2011, 45, 1337-1349.

39. Li, M.; Qi, J.; Zhang, H.; Huang, S.; Li, L.; Gao, D. Concentration and size distribution of bioaerosols in an outdoor environment in the qingdao coastal region. Sci. Total. Environ. 2011, 409, 3812-3819.

40. Xu, Z.; Wei, K.; Wu, Y.; Shen, F.; Chen, Q.; Li, M.; Yao, M. Enhancing bioaerosol sampling by andersen impactors using mineral-oil-spread agar plate. PLoS One 2013, 8, e56896.

41. Rhodes, G.; Henrys, P.; Thomson, B.C.; Pickup, R.W. Mycobacterium avium subspecies paratuberculosis is widely distributed in british soils and waters: Implications for animal and human health. Envir. Microbiol. 2013, 15, 2761-2774. 
42. Primm, T.P.; Lucero, C.A.; Falkinham, J.O. Health impacts of environmental mycobacteria. Clin. Microbiol. Rev. 2004, 17, 98-106.

43. Woodcock, A.H.; Kientzler, C.F.; Arons, A.B.; Blanchard, D.C. Giant condensation nuclei from bursting bubbles. Nature 1953, 172, 1144-1145.

44. Falkinham, J.O. Nontuberculous mycobacteria in the environment. Clin. Chest. Med. 2002, 23, 529-551.

45. Glazer, C.S.; Martyny, J.W.; Lee, B.; Sanchez, T.L.; Sells, T.M.; Newman, L.S.; Murphy, J.; Heifets, L.; Rose, C.S. Nontuberculous mycobacteria in aerosol droplets and bulk water samples from therapy pools and hot tubs. J. Occup. Health. Environ. Hygiene 2007, 4, 831-840.

46. Falkinham, J.O. Mycobacterial aerosols and respiratory disease. Emerg. Infect. Dis. 2003, 9, 763-767.

47. Wendt, S.L.; George, K.L.; Parker, B.C.; Gruft, H.; Falkinham, J.O. Epidemiology of infection by nontuberculous mycobacteria. Iii. Isolation of potentially pathogenic mycobacteria from aerosols. Am. Rev. Resp. Dis. 1980, 122, 259-263.

48. Corner, L.A.L.; Pfeiffer, D.U.; Abbott, K.A. Unanswered questions about the transmission of Mycobacterium avium subspecies paratuberculosis. Vet. J. 2003, 165, 182-183.

49. Corner, L.A.L.; Pfeiffer, D.U.; Abbott, K.A. The respiratory tract as a hypothetical route of infection of cattle with Mycobacterium avium subspecies paratuberculosis. Aus. Vet. J. 2004, 82, $170-173$.

50. Eisenberg, S.W.F.; Nielen, M.; Santema, W.; Houwers, D.J.; Heederik, D.; Koets, A.P. Detection of spatial and temporal spread of Mycobacterium avium subspecies paratuberculosis in the environment of a cattle farm through bio-aerosols. Vet. Microbiol. 2010, 143, 284-292.

51. Eisenberg, S.W.F.; Nielen, M.; Koets, A.P. Within-farm transmission of bovine paratuberculosis: Recent developments. Vet. Quart. 2012, 32, 31-35.

52. Eisenberg, S.W.F.; Koets, A.D.P.; Nielen, M.; Heederik, D.; Mortier, R; de Buck, J.; Orsel, K. Intestinal infection following aerosol challenge of calves with Mycobacterium avium subspecies paratuberculosis. Vet. Res. 2011, 42, 1-9.

53. Mayberry, J. Review of environmental-factors and crohns-disease. Acta Hepato-Gastroenterol. 1979, 26, 257-259.

54. Mayberry, J.; Rhodes, J.; Hughes, L.E. Incidence of crohn disease in cardiff between 1934 and 1977. Gut 1979, 20, 602-608.

55. Rhodes, G.; Fluri, A.; Gerber, M.; Henderson, A.; Ruefenacht, A.; Pickup, R.W. Detection of Mycobacterium immunogenum by real-time quantitative taqman pcr. J. Microbiol. Meth. 2008, 73, 266-268.

56. Kavouras, I.G.; Ferguson, S.T.; Wolfson, J.M.; Koutrakis, P. Development and validation of a high-volume, low-cutoff inertial impactor. Inhal. Toxicol. 2000, 12, 35-50.

57. Kavouras, I.G.; Koutrakis, P. Use of polyurethane foam as the impaction substrate/collection medium in conventional inertial impactors. Aerosol. Sci. Tech. 2001, 34, 46-56.

58. Porter, K.G.; Feig, Y.S. The use of dapi for identifying and counting aquatic microflora. Limnol. Oceanogr. 1980, 25, 943-948.

59. Edwards, U.; Rogall, T.; Blocker, H.; Emde, M.; Bottger, E.C. Isolation and direct complete nucleotide determination of entire genes - Characterization of a gene coding for 16s-ribosomal rna. Nucl. Acids Res. 1989, 17, 7843-7853. 
60. Van Coppenraet, E.S.B.; Lindeboom, J.A.; Prins, J.M.; Peeters, M.F.; Claas, E.C.J.; Kuijper, E.J. Real-time per assay using fine-needle aspirates and tissue biopsy specimens for rapid diagnosis of mycobacterial lymphadenitis in children. Am. J. Clin. Microb. 2004, 42, 2644-2650.

61. Slana, I.; Kralik, P.; Kralova, A.; Pavlik, I. On-farm spread of Mycobacterium avium subsp paratuberculosis in raw milk studied by is 900 and $f 57$ competitive real time quantitative pcr and culture examination. Int. J. Food. Microbiol. 2008, 128, 250-257.

62. Schoenenbrucher, H.; Abdurnawjood, A.; Failing, K.; Buelte, M. New triplex real-time pcr assay for detection of Mycobacterium avium subsp paratuberculosis in bovine feces. Appl. Environ. Microbiol. 2008, 74, 2751-2758.

63. Li, L.L.; Bannantine, J.P.; Zhang, Q.; Amonsin, A.; May, B.J.; Alt, D.; Banerji, N.; Kanjilal, S.; Kapur, V. The complete genome sequence of mycobacterium avium subspecies paratuberculosis. P. Natl. Acad. Sci. USA 2005, 102, 12344-12349.

64. Poupart, P.; Coene, M.; Vanheuverswyn, H.; Cocito, C. Preparation of a specific rna probe for detection of Mycobacterium paratuberculosis and diagnosis of johnes disease. Am. J. Clin. Microb. 1993, 31, 1601-1605.

65. Bustin, S.A.; Benes, V.; Garson, J.A.; Hellemans, J.; Huggett, J.; Kubista, M.; Mueller, R.; Nolan, T.; Pfaffl, M.W.; Shipley, G.L.; et al. The miqe guidelines: Minimum information for publication of quantitative real-time pcr experiments. Clin. Chem. 2009, 55, 611-622.

66. Eisenberg, S.; Nielen, M.; Hoeboer, J.; Bouman, M.; Heederik, D.; Koets, A. Mycobacterium avium subspecies paratuberculosis in bioaerosols after depopulation and cleaning of two cattle barns. Vet. Rec. 2011, 168, 587.

67. Kudo, K.; Sano, H.; Takahashi, H.; Kuronuma, K.; Yokota, S.; Fujii, N.; Shimada, K.; Yano, I.; Kumazawa, Y.; Voelker, D.; et al. Pulmonary collectins enhance phagocytosis of Mycobacterium avium through increased activity of mannose receptors. J. Immunol. 2004, 172, 7592-7602.

68. Storch, I.; Sachar, D.; Catz, S. Pulmonary manifestations of inflammatory bowel disease. Inflamm. Bowel Dis. 2003, 9, 104-115.

69. Bonniere, P.; Wallaert, B.; Cortot, A.; Marchandise, X.; Riou, Y.; Tonnel, A.B.; Colombel, J.F.; Voisin, C.; Paris, J.C. Latent pulmonary involvement in crohn's disease: Biological, functional, bronchoalveolar lavage and scintigraphic studies. Gut 1986, 27, 919-925.

70. Calder, C.J.; Lacy, D.; Raafat, F.; Weller, P.H.; Booth, I.W. Crohn's disease with pulmonary involvement in a 3 year old boy. Gut 1993, 34, 1636-1638.

71. Casey, M.B.; Tazelaar, H.D.; Myers, J.L.; Hunninghake, G.W.; Kakar, S.; Kalra, S.X.; Ashton, R.; Colby, T.V. Noninfectious lung pathology in patients with crohn's disease. Am. J. Surg. Path. 2003, 27, 213-219.

72. Louis, E.; Louis, R.; Shute, J.; Lau, L.; Franchimont, D.; Radermecker, M.; Djukanovic, R.; Belaiche, J. Bronchial eosinophillic infiltration in crohn's disease in the absence of pulmonary disease. Clin. Exp. Allergy 1999, 29, 660-666.

73. Mansi, A.; Cucchiara, S.; Greco, L.; Sarnelli, P.; Franco, M.T.; Santamaria, F. Bronchial hyperresponsiveness in children and adolescents with crohn's disease. Am. J. Resp. Crit. Care 2000, 161, 1051-1054.

74. Hermon-Taylor, J. Gut pathogens: Invaders and turncoats in a complex cosmos. Gut Pathog. 2009, 1, 1-3. 
75. Bannantine, J.P.; Bermudez, L.E. No holes barred: Invasion of the intestinal mucosa by Mycobacterium avium subspecies paratuberculosis. Infect. Immun. 2013, 81, 3960-3965.

76. Naser, S.A.; Ghobrial, G.; Romero, C.; Valentine, J.F. Culture of Mycobacterium avium subsp. paratuberculosis from the blood of patients with crohn's disease. Lancet 2004, 364, 1039-1044.

77. Autschbach, F.; Eisold, S.; Hinz, U.; Zinser, S.; Linnebacher, M.; Giese, T.; Loffler, T.; Buchler, M.W.; Schmidt, J. High prevalence of Mycobacterium avium subspecies paratuberculosis is 900 DNA in gut tissues from individuals with crohn's disease. Gut 2005, 54, 944-949.

78. Di Sabatino, A.; Paccagnini, D.; Vidali, F.; Rosu, V.; Biancheri, P.; Cossu, A.; Zanetti, S.; Corazza, G.R.; Sechi, L.A. Detection of Mycobacterium avium subspecies paratuberculosis (map)-specific is900 DNA and antibodies against map peptides and lysate in the blood of crohn's disease patients. Inflamm. Bowel Dis. 2011, 17, 1254-1255.

79. Sechi, L.A.; Scanu, A.M.; Molicotti, P.; Cannas, S.; Mura, M.; Dettori, G.; Fadda, G.; Zanetti, S. Detection and isolation of Mycobacterium avium subspecies paratuberculosis from intestinal mucosal biopsies of patients with and without crohn's disease in sardinia. Am. J. Gastroenterol. 2005, 100, 1529-1536.

80. Abubakar, I.; Myhill, D.; Aliyu, S.H.; Hunter, P.R. Detection of Mycobacterium avium subsp. paratuberculosis from patients with crohn's disease using nucleic acid-based techniques: A systematic review and meta-analysis. Inflamm. Bowel Dis. 2008, 14, 401-410.

(C) 2014 by the authors; licensee MDPI, Basel, Switzerland. This article is an open access article distributed under the terms and conditions of the Creative Commons Attribution license (http://creativecommons.org/licenses/by/3.0/). 